\section{Future of institute in doubt}

THE future of theoretical nuclear physics in Poland is in some doubt, following the closure last December of the nuclear research institute at Swierk (see Nature $301,103 ; 1983)$. The original institute is to be replaced by three: the Institute of Atomic Energy, the Institute of Chemistry and Nuclear Technology and the Institute of Nuclear Problems. The research programmes and organization of these new institutes are now being worked out. Nothing, so far, has been said about the future of the former Theoretical Physics Division at Swierk.

The reorganization of such an important institute as Swierk is widely believed to have been a cover for a purge of Solidarity activities. Swierk had, for many years, been a focus of dissent - in 1976, two young Swierk scientists, Gregorz Boguta and Miroslaw Chojecki, joined the Workers' Defence Committee (KOR), the civil rights pressure group that paved the way for Solidarity.

In the summer of 1981 when, after an interval of five years, the Polish Government reestablished its Atomic Energy Agency and put it in charge of Swierk, the scientific council of Solidarity at the institute refused to accept the introduction of "Deputy Directors for Security" who would be appointed from the state security apparatus. On the imposition of martial law, Solidarity members at Swierk went on strike, in spite of the new regulations outlawing strike action.

More than 70 Swierk employees were interned, arrested, fined or dismissed. Professor A. Wierusz, director of the nuclear power development programme, and $\mathrm{Dr}$ Zygmunt Luczynski, a specialist on gasphase ion-molecule reactions, were interned and Dr Tadeusz Pacuszka, a leading biochemist, received a two-year prison sentence for participating in a strike. Others were repeatedly interrogated by the police, and were refused passports to attend conferences abroad.

The formal closure of the institute last December meant that even if a researcher expected to continue doing the same job in the same laboratory under the new set-up, he or she had to go through the political verification process imposed on new employees. It also provided a loophole for sacking researchers who had held tenured positions for many years. At least 40 people lost their jobs in this way, including Dr Wierusz and Dr Luczynski (by now out of internment), Dr J. Kownacki (a specialist on heavy nuclei), Dr T. Krogulski (muonic atoms), Dr E. Piasecki (fission) and Dr Zenon Wegrynowicz (a biologist).

According to the Solidarity underground in Warsaw, the proton synchrotron team was particularly hard-hit.

Moreover, instead of being allowed to work out their statutory three months' notice, the dismissed scientists, contrary to Polish law, were not allowed to return to the institute while under notice. They had to collect their-salaries and ration cards outside the institute premises, and their experiments were simply abandoned. The dismissals did not go unmarked by the Polish physics community, and resolutions expressing concern at the manner in which they were carried out have been passed by both the University of Warsaw physics department and the Physics Committee of the Polish Academy of Sciences.

At the end of March 1982, Grzegorz Boguta, the former member of KOR, was refused an extension to his contract, although a position was available within the new structure. This meant that he would be unable to complete his $\mathrm{PhD}$ research in radiobiology. A petition on his behalf was signed by 46 fellow employees in the department of radiobiology (only 3 abstained) but was rejected by the authorities. A few days later, Dr Maria Kopec, his supervisor, who had been particularly active on his behalf, was demoted from her position as head of the depart- ment and has now been forced to take early retirement.

Ironically, and almost simultaneously, the Polish Radiation Research Society awarded its Maria Sklodowska-Curie medal to Dr Kopec and a special prize to $\mathrm{Mr}$ Boguta, and elected Dr Luczynski to its executive board. A few days later, the military commissar for the Swierk complex ordered an investigation into those taking part in the society's elections. The latest rumours suggest that another round of mass dismissals from Swierk is on its way.

Under these circumstances, the outlook of the theoretical physics division looks bleak. Its research teams include such internationally known figures as Dr E. Infeld (the son of Leopold Infeld, one of the founders of Swierk and a colleague of Einstein), Professor R. Raczka (field theory), Professor J. Dabrowski (field theory) and Dr L. Lukaszuk (particle theory). Formally, the decision as to whether to disband the division or to incorporate it into the new structure is the responsibility of $\mathrm{Dr} \mathrm{M}$. Sowinski, the director of the Atomic Energy Agency, although it is hoped that Professor M. Nalecz, who holds a watching brief within the agency on behalf of the Academy of Sciences, will be consulted.

\title{
Changes in UK students' grants
}

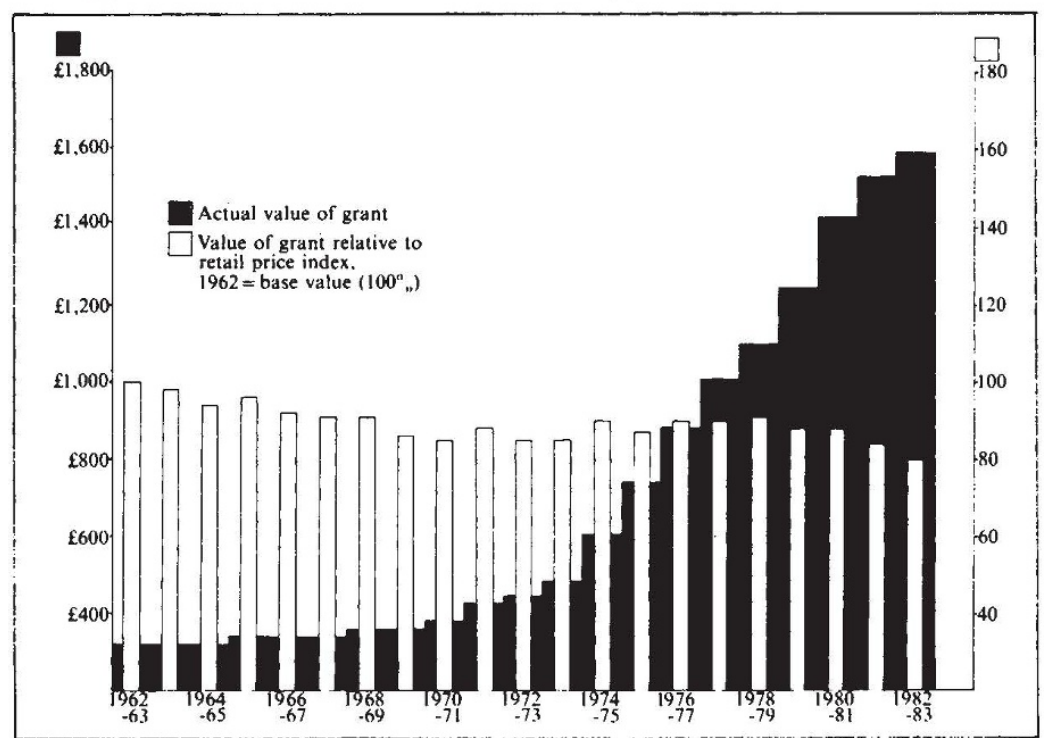

THE recent announcement by the British Government of a 4 per cent rise in the undergraduate student grant has met with widespread discontent, particularly within the National Union of Students (NUS). The undergraduate grant is a mandatory award given to permanent residents of the United Kingdom who are undertaking "designated" further education courses, which include, for example, first degree and teacher training courses. The grant is subject to a parental means test and the dispute is centred around the relative value of the maximum grant which may be awarded to students in England and Wales. The grant for all parts of England and Wales except London currently stands at $£ 1,660$ per year compared with the $£ 255$ given in 1962 when the system of grants was set up. As the chart shows, however, although the money value of the grant has increased 6.5 times over the past 20 years, its value relative to the retail price index has fallen by 20 per cent since 1962 and by 11 per cent in the four years since 1979. In addition, NUS points out that the retail price index is designed to measure the value of the average family income and therefore fails to account adequately for students' living expenses. 